\title{
Biodiesel Fuel- A Review
}

\author{
P. U. Gaikwad ${ }^{1}$, K L Balan ${ }^{1}$, S. S. Sarawade ${ }^{2}$ \\ '(Sathyabama University, Chennai, TamilNadu India) \\ ${ }_{2}^{2}$ (Department of Mechanical Engineering, M. E. S. College Of Engineering, S. P. Pune University, India)
}

\begin{abstract}
Biodiesel is an alternative to conventional diesel fuel made from renewable resources, such as nonedible vegetable oils. The oil from seeds (e.g., Jatropha and Pongamia) can be converted to a fuel commonly referred to as "Biodiesel." No engine modifications are required to use biodiesel in place of petroleum-based diesel. Biodiesel can be mixed with petroleum-based diesel in any proportion. This interest is based on a number of properties of biodiesel including the fact that it is produced from a renewable domestic source, its biodegradability, and its potential to reduce exhaust emissions. The climate change is presently an important element of energy use and development. Biodiesel is considered "climate neutral" because all of the carbon dioxide released during consumption had been sequestered out of the atmosphere during crop growth. The use of biodiesel resulted in lower emissions of unburned hydrocarbons, carbon monoxide, and particulate matter. Biodiesel also increased catalytic converter efficiency in reducing particulate emissions. Chemical characterization also revealed lower levels of some toxic and reactive hydrocarbon species when biodiesel fuels were used. The fuel consumption in the world particularly in developing countries has been growing at alarming rate. Petroleum prices approaching record highs and they will deplete within few decades, it is clear that more can be done to utilize domestic non-edible oils while enhancing our energy security. The economic benefits include support to the agriculture sector, tremendous employment opportunities in plantation and processing. Jatropha and Pongamia are known just crude plants which grow on eroded soils and require a hot climate and hardly any water to survive. These are the strong reasons, enforcing the development of biodiesel plants.
\end{abstract}

Keywords - Biodiesel, Transesterification, Methanol, Jatropha Curcas, fossil fuel.

\section{INTRODUCTION}

Biodiesel is defined as mono-alkyl esters of long chain fatty acids derived from vegetable oils or animal fats which conform to ASTM D6751 ( American Society for Testing \& Materials ). It is the name of a clean burning alternative fuel, produced from domestic, renewable resources and animal fats. Today's diesel engines require a clean -burning, stable fuel that performs well under a variety of operation conditions. It is the only alternative fuel that can be used directly in any existing, unmodified diesel engine. Because it has similar properties to petroleum diesel fuel, biodiesel can be blended in any ratio with petroleum diesel fuel. Specifications for use in diesel engines. Biodiesel refers to the pure fuel before blending with diesel fuel. Biodiesel blends are denoted as "BXX" with "XX" representing the percentage of biodiesel contained in the blend (ie: B20 is $20 \%$ biodiesel, $80 \%$ petroleum diesel). It is simple to use, biodegradable, nontoxic, and essentially free of sulfur and aromatics. It is made though a chemical process called transesterification where by the glycerin is separated from the fat or vegetable oil. Fuel-grade biodiesel must be produced to strict industry specifications in order to insure proper performance. It is better for the environment because it is made from, renewable resources and has lower emissions compared to petroleum diesel. It is less toxic than table salt and biodegrades as fast as sugar. It can be made in India from renewable resources such as Jatropha and Pongamia. Its use decreases our dependence on foreign oil and contributes to our own economy.Dr. Rudolf diesel actually invented the diesel engine to run on a myriad of fuels including coal dust suspended in water, heavy mineral oil and you guessed it, vegetable oil. Dr. Diesel's first engine experiments were catastrophic failures. But by the time he showed his engine at the World Exhibition in Paris in 1900, his engine was running on 100\% peanut oil. Dr. Diesel was visionary. In 1911 he stated "The diesel engine can be fed with vegetable oils and would help considerably in the development of agriculture of the countries which use it. "In 1912, Diesel said, "The use of vegetable oils for engine fuels may seem insignificant today. But such oils may become in course of time as important as petroleum and the coal tar products of the present time". Since Dr. Diesel's untimely death in 1913, his engine has been modified to run on the polluting petroleum fuel we now know as "diesel". Nevertheless, his ideas on agriculture and his invention provide the foundation for a society with clean, renewable, locally grown fuel. 


\section{ESTERIFICATION AND TRANSESTERIFICATION REACTIONSS}

Both the oils contain higher FFA. A two stage process was used for conversion. The first stage (acid catalysed) of the process is to reduce the FFA content of feedstock oil by esterification with methanol $(99 \%$ pure) and acid catalyst sulphuric acid (98\% pure) in one hour time at $60 \pm 65 \mathrm{oC}$ in a closed reactor vessel. The 0.5 wt \% of sulphuric acid and 8:1 molar ratio of alcohol were found sufficient to lower FFA for both the selected feedstocks oil. Methyl alcohol is added in excess amount to speed up the reaction. This reaction was processed with stirring at $650 \mathrm{rpm}$. The major obstacle to acid catalysed esterification for FFA is the water formation. Water can prevent the conversion reaction of FFA to esters from going to completion19. After dewatering the esterified oil was fed to the transesterification process 12. The esterified oils that having lower FFA contents are now ready for transesterification reaction. In this reaction, solid catalysts like homogeneous or heterogeneous were used. Transesterification of Pongamia oil was carried out by using ZnO, H $\beta$ - Zeolite and Montmorillonite K-10 as catalyst (11.5wt. \% of oil) to yield biodiesel at $120 \mathrm{oC}$ with 1:10 molar ratio of oil to methanol. They required longer reaction time $(24 \mathrm{~h})$ and the conversion was $83 \%$ for $\mathrm{ZnO}$, while $\mathrm{H} \beta$ - Zeolite and montmorillonite K-10 catalyzed transesterification gave low conversion of 59 and $47 \%$ respectively 10 . Lu et al. had resulted $97 \%$ of conversion and $98 \%$ of yield of jatropha FAME using 6:1 moral ratio (alcohol to oil), $1.3 \mathrm{wt} \%$ of $\mathrm{KOH}$, at $64 \mathrm{OC}$, in $20 \mathrm{~min}$ with agitation of $1500 \mathrm{rpm} 12$. However Karmee et al has been resulted $92 \%$ yield of pongamia oil ester with 10:1 molar ratio (methanol to oil), $1 \mathrm{wt} \% \mathrm{KOH}$ at $1050 \mathrm{C}$, in 1.5 hrs of time05. Chavan et al. has used $0.5 \%$ of $\mathrm{KOH}$, as a solid homogeneous catalyst along with 6:1 methyl alcohol, as a solvent that yielded $90 \%$ of jatropha FAME in 60 min. Further she has been studied ecofriendly calcined egg shell catalyst as a heterogeneous catalyst in transesterification of Jatropha oil. The catalyst was prepared by calcination of waste egg shells at 900 oc for $2 \mathrm{hrs}$ which then characterised by Differential thermal analysis (DTA), X-ray diffractometer (XRD), Scanning electron microscopy (SEM) and Fourier transform infrared (FTIR) spectroscopic methods. The 8:1 molar ratio (methanol to oil) was found sufficient to convert triglycerides of jatropha oil to its ester while $2.0 \mathrm{wt} \%$ calcined $\mathrm{CaO}$ catalyst was required for optimum yield. This quantity of catalyst is almost double than the chemical catalysts like $\mathrm{KOH}$ or $\mathrm{NaOH}$. The next important factor is reaction time. $2.5 \mathrm{hrs}$ was found sufficient to give $90 \%$ of yield at $600-650 \mathrm{rpm}$ agitation23. Further the equivalent reaction parameters were studied by Madhu et al. using Pongamia oil as feedstock oil and ecofriendly calcined crab shell as a heterogeneous catalyst. He found that $2.5 \mathrm{wt} \%$ of $\mathrm{CaO}, 8 ; 1$ molar ratio, 120 min reaction time, $650 \mathrm{C}$ reaction temperature, at $700 \mathrm{rpm}$ agitation intensity that given $94 \%$ of yield of pongamia FAME06

\section{BENEFITS OF USING BIODIESEL}

- Waste vegetable oil can be used

- Burns cleaner than petro diesel

- Lubricates very well

- Reduces petroleum consumption

- Waste vegetable oil can be used

- Burns cleaner than petro diesel

- Lubricates very well

- Reduces petroleum consumption

\section{OBJECTIVES}

- To get an better alternative source of fuel.

- To conserve non-renewable natural resources

- To obtain less pollutant biodiesel to reduce the emission of toxic gases.

- To control the global warming and green house effects.

- To increase the engine performance using bio-fuels

\section{Transesterification}

- It is the chemical process in which the vegetable oil or waste cooking oil or oil from animal fats gets coverted into biodiesel.

- The vegetable oil esters contain more oxygen and lower calorific value than diesel.

- $\quad$ So to improved properties and get good performance in CI engine, transesterification process is necessary. 
III.

\section{EXPERIMENTAL SETUP: TRANSESTERIFICATION}

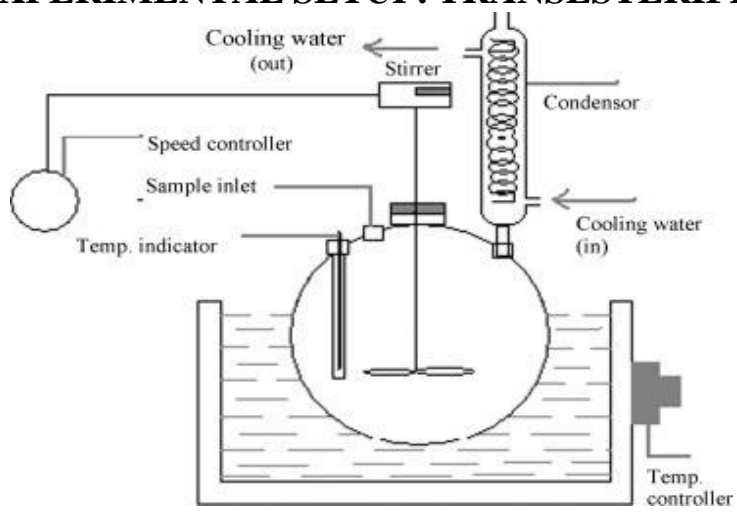

Fig.1:

After Transesterification properties improved

- fuel properties kinematic viscosity; calorific value, density, flash point, and fire point gets improved.

- These parameters induce good combustion characteristics in vegetable oil esters.

- Physical and chemical properties are more improved in esterified vegetable oil because esterified vegetable oil contains more cetane number than diesel fuel.

- Viscosity Decreases.

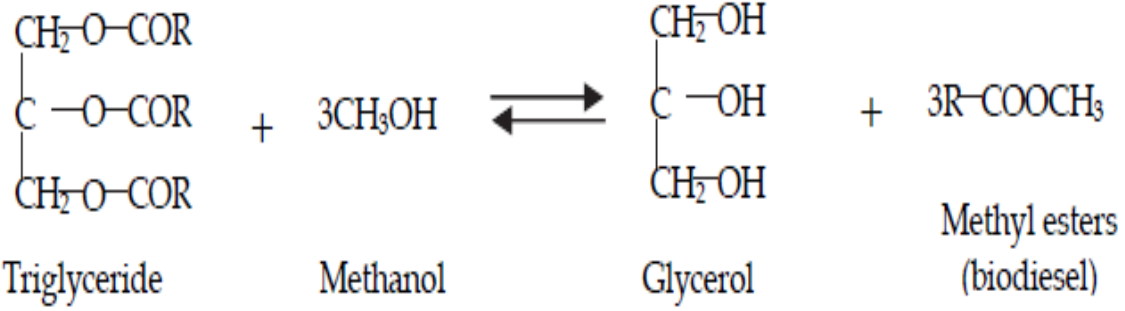

Fig.2: Reaction for oil transesterification.

Properties improved of palm methyl ester as compare to conventional petro diesel.

\begin{tabular}{|l|l|l|}
\hline Properties & Petro Diesel & Palm Methyl Ester Biodiesel \\
\hline Kinematic viscosity & 4.0 & 4.54 \\
\hline Flash point & 35 & $>60$ \\
\hline Density & $820-845$ & 860.6 \\
\hline Calorific value & 44800 & 41781 \\
\hline Cetane number & 51 & 65 \\
\hline
\end{tabular}


Properties improved of neem methyl ester as compare to conventional petro diesel.

\begin{tabular}{|l|l|l|}
\hline Properties & Diesel & $\begin{array}{l}\text { Biodiesel(Neem oil methyl } \\
\text { ester) }\end{array}$ \\
\hline Specific gravity $\left(\mathrm{gm} / \mathrm{cm}^{3}\right)$ & 0.823 & 0.920 \\
\hline Calorific value $(\mathrm{kj} / \mathrm{kg})$ & 43000 & 39000 \\
\hline Cetane number & 48 & 47 \\
\hline Kinetic viscosity $\left(\mathrm{at4} 4{ }^{\circ} \mathrm{C}\right)[\mathrm{cSt}]$ & 3.9 & 38 \\
\hline Chemical formula & $\mathrm{C}_{14} \mathrm{H}_{22}$ & $\mathrm{C}_{18} \mathrm{H}_{34} \mathrm{O}_{2}$ \\
\hline Flash point $\left({ }^{\circ} \mathrm{C}\right)$ & 56 & 245 \\
\hline Fire point $\left({ }^{\circ} \mathrm{C}\right)$ & 64 & 276 \\
\hline Stoichiometric A/F & 15 & 12.41 \\
\hline Carbon $(\%)$ & 86 & 78.92 \\
\hline Hydrogen $(\%)$ & 14 & 13.41 \\
\hline
\end{tabular}

\section{METHODOLOGY}

Identify the important feedstock for biodiesel:- Selected feedstock will beused for biodiesel production. Out of thissuitable feedstock for Indian situations will be decided.Selection of Feedstock for biodiesel as follows.Karanja- Karanja grows naturally through much of arid India, having very deep roots to reach water, and is one of the few crops well-suited to commercialization by India's large population of rural poor. The tree is hardy, reasonably drought resistant and tolerant to salinity. The Karanja tree is of medium size, reaching a height of 15-25 meters. The tree bears green pods which after some 10 months change to a tan color. The pods are flat to elliptic,5-7 $\mathrm{cm}$ long and contain 1 or 2 kidney shaped brownish red kernels. The yield of kernels per tree is reported between 8 and $24 \mathrm{~kg}$. The oil content varies from 27\%- 39\%. The seeds are wasted every year. The main objective of work to utilize these waste oil to convert into value added product, biodiesel.This plant was considered as a reference plant.

\section{Turmeric leaf oil-}

We all are we aware about turmeric plant and its metitional applications. After harvesting of turmeric buds, leaves get waste that contains aromatic, transparent oil having higher density and viscosity. Yet no work was reported on use of turmeric leaf oil for synthesis of biodiesel using heterogeneous catalyst.

\section{Pongamia Pinnata-}

The Pongamia Pinnata is a native of the Western Ghats and is chiefly found along the banks of streams and rivers or near the sea on beaches and tidal forests. It also grows in dry places far in the interior. It is a hardy tree that mines water for its needs from 10 meter depths without competing with other crops. It grows all over the country, from the coastline to the hill slopes. It needs very little care and cattle do not browse it. It has rich leathery evergreen foliage that can be used as green manure.

- Planting density - 200 to 250 per Acre

- Productivity - Starts yielding pods from 3 rd year onwards, but the mature average of $150 \mathrm{~kg}$ prods per tree per year from 10 th year onwards

- Life Span - 100 years

- Yield per hectare / year -6 to 9 tonnes.

Each tree can yield 40 Liters of oil, $120 \mathrm{Kg}$ of fertilizer grade oil cake and $250 \mathrm{Kg}$ of biomass as green manure per year. When in bloom, the Pongamia trees can be used for bee harvesting and honey production. The long term adverse impacts of mono cropping of Pongamia and even Jatropha need to be evaluated and confirmed.

\section{REFERENCES}

[1] Feng Guo,Ning-Ning Wei, Zhi-Long Xiu, Zhen Fang Transesterification mechanism of soybean oil to biodiesel catalyzed by calcinedsodium silicate. Fuel 93 (2012) 468-472

[2] N. Viriya-empikul, P. Krasae , W. Nualpaeng, B. Yoosuk, K. FaungnawakiBiodiesel production over Ca-based solid catalysts derived from industrial wastes Fuel 92 (2012) 239-244

[3] HamedMootabadi, BabakSalamatinia, Subhash Bhatia, Ahmad ZuhairiAbdullah,Ultrasonic-assisted biodiesel production process from palm oil using alkaline earth metal oxides as the heterogeneous catalysts Fuel 89 (2010) 1818-1825 
[4] Hong-yanZeng, Zhen Feng, Xin Deng, Yu-qinLiActivation of Mg-Al hydrotalcite catalysts for transesterification of rape oil. Fuel 87 (2008) 3071-3076

[5] ErtanAlptekin, Mustafa CanakciOptimization of transesterification for methyl ester production from chicken fat , Fuel 90 (2011) 2630-2638

[6] Rubi Romero, Sandra Luz Martínez and Reyna NatividadBiodiesel Production by Using Heterogeneous Catalysts.

[7] SirichaiChantara-arpornchai, Biodiesel Production from Palm Oil using Heterogeneous Base catalyst, International Journal of Chemical and Biological Engineering 62012

[8] Alexandre C. Dimian, "Interrelation of Chemistry and Process Design in Biodiesel Manufacturing by Heterogeneous Catalysis," Top Catal (2010) 53:1197-1201

[9] R.K. Mandloiet. al. / The Effect of Bio-Fuel Blends and EngineLoad on Diesel Engine Smoke Density for Sustainable Environment International Journal of Engineering Science and Technology Vol.2(10), 2010, 5902-5906

[10] Nanthagopal K.,ThundilKaruppa Raj R. and VijayakumarT., Performance and emission characteristics of karanja methyl esters: Diesel blends in a direct injection compression-ignition (CI) engine, Journal of Petroleum Technology and Alternative Fuels Vol. 3(4), pp. 36-41, April 2012

[11] S.Antony Raja, D.S.Robinson smart, and C.Lindon Robert Lee. Biodiesel production from jatropha oil and its characterization. Research Journal of Chemical Sciences Vol. 1 (1) April (2011)

[12] KaziMostafijur Rahman, Mohammad Mashud, Md. Roknuzzaman and Asadullah Al Galib. Biodiesel from Jatropha Oil as an Alternative Fuel for Diesel Engine.International Journal of Mechanical \& Mechatronics Engineering IJMME-IJENS Vol:10 No:03

[13] V.R. Sivakumaret. al. Statistical Analysis On The Performance Of Engine With Jatropha Oil As An Alternate Fuel . International Journal of Engineering Science and Technology Vol. 2(12), 2010, 77407757.

[14] S.Hawash, G.ElDiwani, E.Abdel Kader. Optimization of Biodiesel Production from Jatropha Oil By Heterogeneous Base CatalysedTransesterification.JESTVol. 3 No. 6 June 2011

[15] IttiponWorapun,KulachatePianthong and PrachasantiThaiyasuit, Synthesis of biodiesel by two-step transesterification from crude jatropha curcus L.oil using ultrasonic irradiation assisted KKU Engineering Journal Vol.37 No.3 (169-179) July 3 September 2010 